\title{
Ulayat Land as a Wakf Object According to Law No 41 Year 2004 Case Study Todairi District Berampu
}

\author{
Muhammad Aidil Hanafi ${ }^{1}$, Md. Yadi Harahap ${ }^{2}$, Ramadhan Shahmedi Siregar ${ }^{3}$ \\ 1,2,3Universitas Islam Negeri Sumatera Utara, Indonesia
}

\begin{abstract}
:
Waqf is one of the Islamic philanthropy that carries the common interest. In the order of life, the Muslim community in the district of Berampu, Dairi district, is a Muslim minority. But even so, the spirit and practice of carrying out their religion is very strong. In this regard, including the concern is the spirit of the community to develop and increase the benefits of ulayat land, ulayat land is also waqf.This research aims to Knowing the position of ulayat land as an object of waqf by the people of Berampu sub-district, Dairi district in terms of Law No. 41 of 2004. To answer these problems, a field research was conducted with a qualitative research analysis model which was analyzed through a positive legal theory approach and Islamic law. Based on the results of the study it is known that the implementation of customary land waqf carried out by the people of the Berampu sub-district, as the researchers described earlier is not in accordance with Law No. 41 of 2004 concerning waqf. This is because 1)Customary land is not an object of waqf. This can be seen in PP No. 24 of 1997 in lieu of PP No. 10 of 1961 which states that customary land is not the object of land registration, while in PP no. 24 of 1997, waqf land is the object of land registration. So from this it can be seen that ulayat land is not actually an object of waqf. Because the object of waqf is land that has been registered in accordance with applicable regulations. 2) The practice of waqf carried out by the community of Berampu sub-district, Dairi Regency, is still mostly done verbally and not before PPAIW and is only based on mutual trust without any irar waqf deed as authentic evidence that the land has been waqfed for use in the public interest. As for the factors that cause the practice of waqf of ulayat land in Berampu sub-district, Dairi district are 1) Lack of public knowledge about waqf regulations in Indonesia. 2) The community still holds strongly to customs and habits that have been passed down from generation to generation. 3) The desire of the community to do charity through waqf institutions but not accompanied by knowledge.
\end{abstract}

\section{Keywords:}

waqf; islamic law; community

\section{Introduction}

Islam is a religion that has a high social concern. The economic sector is included in the spotlight of this concern, one form of which is the existence of waqf institutions. Waqf institutions are part of the embodiment of social justice in Islam which has the principle that property should not be controlled by certain groups, but must be revolving so as to prevent social inequality (Khosyi'ah, 2004).

Waqf is a form of charity whose rewards will continue to flow as long as the waqf property is utilized (Marpaung, 2020). Waqf can improve and strengthen the relationship between humans and humans in muamalah, namely in terms of benefits when waqf assets are developed in accordance with the conditions and situations in a place (Nasution et al, 2021). The issue of waqf in Indonesia is regulated in the Compilation of Islamic Law (KHI), to be precise in Chapter III concerning Waqf Law. However, in reality 


\section{Britain International of Humanities and Social Sciences (BIoHS) Journal \\ ISSN: 2685-3868(Online), 2685-1989(Print) \\ Vol. 3, No. 3, October 2021, Page: 422-428}

there are many shortcomings, considering that the position of the Compilation of Islamic Law is a non-binding Presidential Instruction. Therefore, the creation of Law Number 41 of 2004 concerning Waqf, which is also known as the Waqf Law, is something that is awaited by those who are involved in waqf issues, both from academics and practitioners (Hasanah, 2008).

Many developments regarding waqf are regulated in the Waqf Act. One of them is regarding waqf objects, which are not only land rights, but have been developed with other rights as regulated in the Basic Agrarian Law and PP. No. 40 of 1996. Among the rights that can become the object of waqf in the Waqf Law are property rights, use rights, building rights, use rights, and management rights.

\section{Research Methods}

The research method is a way of doing something by using the mind carefully to achieve a goal by searching, recording, formulating, and analyzing to compile a report. The term methodology comes from the word method which means a way, however, according to custom, the method is formulated with the possibilities of a type used in research and assessment (Soekanto, 2012). In preparing this thesis, the author uses the following methods:

\subsection{Types of research}

Determining the type of research before going into the field is very important. Because this type of research is an umbrella that will be used as the main basis for conducting research (Moleong, 2002). Therefore, the determination of the type of research must be based on the right choice because it will have implications for the whole research.

This research is included in the type of empirical juridical research, or called field research, namely examining the applicable legal provisions and what happens in reality in society (Arikunto, 2012). Empirical juridical research is legal research regarding the enforcement or implementation of normative legal provisions in action on certain legal events that occur in society (Muhammad, 2004). Or in other words, that is a research conducted on the actual situation or real conditions that occur in the community with the intention of knowing and finding the facts and data needed, after the required data is collected then leads to problem identification which ultimately leads to problem solving (Waluyo, 2002).

\subsection{Research Approach}

The approach method used in this research is a sociological juridical approach. The sociological juridical approach is to identify and conceptualize law as a real and functional social institution in a real life system. The sociological juridical approach emphasizes research that aims to obtain legal knowledge empirically by going directly to the object, namely ulayat land as the object of waqf.

The statutory approach is carried out by examining all regulations or laws and regulations relating to legal issues to be studied, namely research on ulayat land which is used as the object of waqf in terms of Law Number 41 of 2004 concerning waqf. 


\section{Results and Discussion}

The procedures and procedures for waqf are regulated in Law Number 41 of 2004 starting from the preparation of waqf implementation, registration of waqf objects, to recording the waqf pledge in the Waqf Pledge Deed (AIW). The registration of all waqf objects is carried out to maintain administrative order and to obtain recognition and guarantees of protection from the state which are regulated through laws and regulations. The legislation in question is Law no. 5 of 1960 concerning Basic Agrarian Regulations, Government Regulation Number 10 of 1961 concerning Land Registration, Government Regulation Number 24 of 1977 concerning Regulation of Owned Land Waqf, Presidential Instruction Number 1 of 1991 concerning Compilation of Islamic Law, and finally Law Number 41 of 2004 concerning Waqf.

The practice of waqf carried out by the people of Berampu sub-district, Dairi district, as the researchers described previously, is not in accordance with regulations. This is because:

1. The community makes ulayat land as an object of waqf, where ulayat land is jointly owned land by indigenous peoples.

2. The practice of waqf carried out by the people of the Berampu sub-district, Dairi Regency, is mostly still carried out orally and not before PPAIW. Although in Article 17 paragraph (2) the waqf pledge may be made orally, it must still be made before PPAIW.

3. The practice of waqf carried out by the people of the Berampu sub-district of Dairi Regency is only based on mutual trust without any waqf pledge deed as authentic evidence that the land has been waqfed for use in the public interest. Meanwhile, in the Waqf Law, it is regulated that every waqf must be recorded, as explained in Article 17 paragraph (2) which reads: "The Waqf Pledge is stated orally and/or in writing and is stated in the waqf pledge deed by PPAIW." The Waqf Pledge Deed (AIW) was made to create legal certainty for the waqf land.

By looking at the provisions of waqf in the Basic Agrarian Law and its implementation provisions, it is not possible to waqf of ulayat land, including in Law Number 41 of 2004, waqf of ulayat land is also not possible, because what can become the object of waqf is fixed objects such as land, which is property rights to cultivate, right to build, right to use and state land, while customary land is not the same as land with ownership rights, right to cultivate, right to build, and right to use.

All types of rights mentioned by Law Number 41 of 2004 are rights whose ownership is individual, while customary land does not belong to individuals. Customary land is also not the same as land controlled by the state, because in principle the land controlled by the state is at the highest level which has not been entitled with other rights, in addition the state is affirmed that it does not own land but only controls lands on Indonesian soil to regulate, both the use, designation, utilization, provision and maintenance of land. In addition, the State is only tasked with regulating legal relations in the form of land rights in Indonesia and also legal actions whose object is land, through land registration. This is to provide legal certainty regarding land rights.

Customary rights are not explicitly stated as land rights, because the regulation is also specified in Article 3 of the Basic Agrarian Law, but it is also not included in Article 2 concerning the right to control from the state. There has been a debate over the interpretation of Ulayat Rights until now. On the one hand, mentioning Ulayat Rights as undivided common property rights is a legal concept that must be formulated further in the organic provisions of the Basic Agrarian Law or implementing regulations of the Basic Agrarian Law. Meanwhile, 
on the other hand, it states that customary rights are not rights to land with the concept of full rights to their owners by law, but are a form of respect for the legal community to take benefits from the land or customary rights (Mirwati, 2016).

Therefore, ulayat rights are not a concept of rights as they must have elements of the subject of the right and the object of the right. The subject of the rights of indigenous peoples has not been recognized as a subject of rights, therefore the enjoyment that is taken and utilized is a respect for the right to control the state.

Based on the absence of unity of opinion regarding ulayat rights as land rights in the legal concept, ulayat rights until now cannot be registered, in accordance with land registration regulations it does not state that ulayat land is the object of land registration (PP No. 24 of 1997 in conjunction with PP No. 10 of 1961).

In the original land waqf in Indonesia, only property rights to land that could be waqf were stated (Article 49 of the Basic Agrarian Law), the implementation of which was regulated in PP. 28 of 1977, which appoints waqf land registration based on PP No. 10 of 1977. Likewise with the development of waqf in Law No. 41 of 2004 whose implementation is regulated in PP. 42 of 2006, the registration of waqf lands is carried out with PP No. 24 of 1997.

In PP No. 24 of 1997, indeed waqf land is the object of land registration, but the lands that can be waqf in Law Number 41 of 2004 are property rights, right to cultivate, right to build and use right, and or state land, it is not stated wrongly. The other is ulayat land as stipulated in Article 3 of the Basic Agrarian Law.

Although in the Basic Agrarian Law it has been shown that waqf land registration is carried out with the provisions of land registration, it turns out that ulayat lands in the community are mostly not registered. In the subsequent development of waqf provisions contained in the Waqf Law, the implementation of waqf land registration is carried out by PP No. 24 of 1997, however, the registration of waqf land originating from ulayat land is not stated. Based on this, legally the provisions regarding waqf administration through waqf land registration cannot be carried out with the two land registration provisions.

However, in reality, in the community of Berampu sub-district, Dairi district, waqf land registration is carried out with the provisions of land registration as stipulated in the Basic Agrarian Law. Thus, customary land is implicitly recognized by the community as property rights which are the same as property rights in the concept of the Basic Agrarian Law. In fact, customary rights are not the same as the concept of property rights of the Basic Agrarian Law, because the subject of customary rights is customary law communities, not individuals or joint ownership of people who are in individual concepts.

Thus, the practice of waqf of ulayat land carried out by the people of Berampu subdistrict, Dairi district has violated waqf regulations in Indonesia, especially Law No. 41 of 2004. 


\section{Conclusion}

From the research that has been done, the researchers can draw conclusions. The conclusions are:

1. Provisions regarding waqf objects are regulated in Articles 15 and 16 of Law Number 41 of 2004. Article 15 reads "Waqf property can only be donated if it is legally owned and controlled by the Waqif". This means that if the property to be waqf is a disputed land, or in the form of property that is still under guarantee, it cannot be used as an object of waqf. Waqf objects in the legislation consist of immovable objects and movable objects. Immovable objects as referred to in paragraph (1) letter a Article 16 of Law No. 41 of 2004 cover five things, namely:

a. Land rights are in accordance with the provisions of applicable laws and regulations, both those that have been and have not been registered

b. The building or part of the building that stands on the ground as referred to in letter a

c. Plants and other objects related to the soil

d. Ownership rights to the apartment unit in accordance with the provisions of sharia and applicable laws and regulations

e. Other immovable objects in accordance with sharia provisions and applicable laws and regulations.

Meanwhile, waqf objects which include movable objects are property that cannot be exhausted due to consumption, such as:

a. Money

b. Precious metal

c. Securities

d. Vehicle

e. Intellectual property rights

f. Rental rights

g. Other movable objects in accordance with sharia provisions and applicable laws and regulations.

2. There are several important points regarding the application of ulayat land as an object of waqf in the community of Berampu sub-district, Dairi district, among others:

a. The ulayat lands controlled by sulang silima (customary leaders) have shifted ownership so that they are controlled by individuals. In one case, the ulayat land was registered personally with the National Land Agency as private land, and in the other case, the ulayat land was registered with the village head as private land. The ulayat land which has been privately controlled is then registered as waqf land before the official registrar of the waqf pledge deed (PPAIW), so that the waqf land has AIW (waqf pledge deed).

b. The ulayat land is waqfed by Sulang Silima but does not have a waqf pledge deed. The implementation of customary land waqf like this is done orally and not before PPAIW. The practice is only based on mutual trust between them, and the land does not have a waqf pledge deed as authentic evidence that the land has been waqf for use in the public interest.

3. The existence of ulayat land as waqf object is not supported by the provisions governing waqf including Law Number 41 of 2004. In other words, the Waqf Law does not regulate ulayat land as waqf object.In the Basic Agrarian Law and various other regulations, it can be seen that the regulated land waqf is only a type of property right. Although later the object of land waqf was developed with other types of land such as cultivation rights, building use rights and use rights, there was still no ulayat right as the object of waqf. So, customary land which is used as an object of waqf by the people of Berampu sub-district, Dairi district has violated the law. 


\section{Suggestion}

The suggestions that the author can give related to this research are as follows:

1. The government is expected to make regulations on ulayat land waqf and socialize these regulations to the people who have ulayat land in their area considering the reality in the community that has made ulayat land as an object of waqf.

2. The local preachers, asatidz, penghulu and Islamic religious educators should also take part in providing knowledge to the public about land waqf in Islam so that there are no unexpected mistakes regarding the position of ulayat land as waqf objects.

3. The community should be more concerned and proactive in undergoing regulations regarding waqf, namely Law No. 41 of 2004.

\section{References}

Agus Rusanto, Criminal Acts and Criminal Liability, Jakarta, Prenadamedia Group 2016;

Alex, Contemporary Popouler Scientific Dictionary, Surabaya: Karya Harahapan, 2005;

Arikunto, S. (2012). Research Procedure A Practical Approach (Jakarta: Rineka Cipta), p. 126.

Malthuf Siroj, Corruption in the Perspective of Islamic Law and its Eradication Strategy, In Al-Ihkam Journal, December 2016;

Andi Hamzah, Principles of Criminal Law in Indonesia \& Its Development, Jakarta: Sofmedia, 2012

Anugrahni, Approaches to Legal Research, chatlin Hukum.wordpres.com;

Asep N. Mulyana, Corrupt Dimensions of Public (Official) Policy, Jakarta: Madju Publisher, 2016;

Binoto Nadapdap, Corruption Is Not Dead, Jakarta, Permata Aksara 2014;

Boedi Abdullah and Beni Ahmad Saebani, Comparison of Fiqhiyah Rules, Bandung: Faithful Library 2018;

Constitutional Court, 1945 Constitution of the Republic of Indonesia, Jakarta: Registrar and Secretariat General of the Constitutional Court, 2013;

Ministry of Religion of the Republic of Indonesia, Al-Quran and its Translation, Jakarta: Ministry of Religion of the Republic of Indonesia, 2002;

Ermansyah Djadja, Redesigning the Corruption Court, Jakarta: 2010, Sinar Graphic, 2010

Evi Hartanti, Corruption Crime, Jakarta, Cet. Fifth, Sinar Graphic 2018;

ECW, Neloe, Bank Loans Become Corruption Crimes, Jakarta: Verbun Pubishing 2012;

Fathan Qorib, Attorney General: Offenders Can Be Charged with Anti-Corruption Law, Jakarta: Hukumonline, on October 21, 2016

Focusindo Mandiri, Law on the Eradication of Criminal Acts of Corruption, Bandung: 2013;

Ibnul Manzur, Lisan al Arab, Beirut: Daru Sadir, 1998

Izomiddin, Thought and Philosophy of Islamic Law, Jakarta: Prenadamedia Group, 2010

Jawade Hafidz Arsyad, Corruption in the Perspective of HAN (State Administration Law), Jakarta, Sinar Graphic 2017;

Jimly Assiddiqie, Hans Kelson About Law, Jakarta: Konpress, 2012

Kamisa, Big Indonesian Dictionary, Surabaya, Kartika, 1997;

Kesumo Wardoyo, What Are Ghulul and Its Dangers That We Must Avoid, Sunday Morning Study, at the Al-Falah Grand Mosque/https:/mesjidrayalfalah.or.id.2014;

Komariah E. Supardjaja, Says Corruption Has Hindered Domestic Investment Seminar on Law Enforcement Institutions in Indonesia, Jakarta: Research and Development Center for the Indonesian Attorney General's Office, 19 November 2009;

Kristian, Yopi Gunawan, Corruption Crimes (Study of Harmonization Between National Law and The United Nation Against Corruption (UNCAC), Bandung: Refika Aditama, 2015 ; 
Law No. 31 of 1999 concerning the Eradication of Criminal Acts of Corruption as amended by Law of the Republic of Indonesia No. 20 of 2001 concerning Amendments to Law No. 31 of 1999 concerning the Eradication of Corruption Crimes, Jakarta: Focusindo Mandiri, 2013;

Louwis Ma'luf al Yassu'i, Al Munjid fi allughah wa ala'lam, Beirut: Dar al Masyriq, 2017;

M. Nurul Irfan, Corruption in Islamic Criminal Law, Jakarta: Amzah, 2012;

Marpaung, A. (2020). Increasing Economic Empowerment of the People through Productive Waqf. Britain International of Humanities and Social Sciences (BIoHS) Journal. Vol. 2, No. 3, Page: 632-642.

Maidin Gultom, An Analysis of Corruption in Indonesia, Bandung, PT. Refika Aditama 2018; Mia Amiati Iskandar, Expanding Participation in Corruption Crimes according to UNCATOC 2000 and UNCAC 2003, Jakarta, GP Press Group, 2013;

Munir Fuady, Theory-Theory in Legal Sociology, Jakarta: Jakarta Kencana, 2011;

Moeljatno, Principles of Criminal Law, Jakarta: Rineka Cipta, 2008;

Moleong, L. J. (2002). Qualitative research methodology (Bandung: PT. Rosda Karya), p. 135.

Muhammad, A. (2004). Law and Legal Research, (Bandung: Citra Aditya Bakti), p.134.

Muhammad Abu Zahrah, Al Jarimah Wal Uqubah fi Fiqhil Islam Al Jarimah, Cairo: Dar al Araby, 1998;

Muhammad Iqbal Siddiqi, The Penal Law, New Delhi: International Islamic Publisher, 1994;

Muhammad Wasitho Abu Fawaz. Bribery that is Halal and Haram in Religion, Muslim Entrepreneur Magazine, April 2012 Edition;

Mustofa Hasan and Beni Ahmad Saebani, Islamic Criminal Law, Fiqh Jinayat, Bandung: Faithful Library 2013;

Nasaruddin Umar, Corruption Theology, Jakarta, PT. Elex Media Komputindo, 2019;

Nasution, Y., et al. (2021). Analysis of Wakaf and Maqashid Syari'ahLaw on the Development of Wakaf Property in Lhokseumawe City. Britain International of Humanities and Social Sciences (BIoHS). Vol. 3, No.1, Page: 224-231.

Palmawati Tahir and Dini Handayani, Islamic Law, Jakarta: Sinar Graphic, 2019;

PAF Lamintang, Fundamentals of Indonesian Criminal Law, Bandung: PT. Citra Aditya Bakti 2017;

R. Sugandhi, KUHP With Explanation, Surabaya: National Enterprise 1980;

R.Widyo Pramono, Eradication of Corruption and Other Crimes a Perspective of Prosecutors and Professors, Jakarta: Kompas Media Nusantara, 2016;

Sayyid Sabiq, Fiqh Sunnah, Bandung: Al Ma'arif, 1987;

Shidarta and Petrus Lakonawa, Lex Specialis Derogat Legi Generalli, Meaning and Use, Business-law.binus.ac.id,

Soenarto Soedibroto, Criminal Code and Criminal Procedure Code, Jakarta: PT. Raja Grapindo Persada, 2014;

Sudikono Mertkusumo, The Discovery of An Introduction to Law, Yogyakarta: liberty, 2006;

Sufiar Rahman, Al Misbah Al Munir, Riyadh: Dar al Salam, 2014;

Suhartoyo, Arguments for Reversing the Burden of Evidence, as a Priority Method in Combating Corruption and Money Laundering, Jakarta: PT. Rajagrafindo, 2019;

Wahbah al-Zuhaily. (1998). al figh al-Islami wa fairlatuh, Issue 4, Volume 6, Beirut: Dar Al Fikr.

Waluyo, B. (2002). Legal Research in Practice, (Jakarta: Sinar Graphic), p. 15. 